Historic, Archive Document

Do not assume content reflects current scientific knowledge, policies, or practices. 



\section{FALL PRICE LIST}

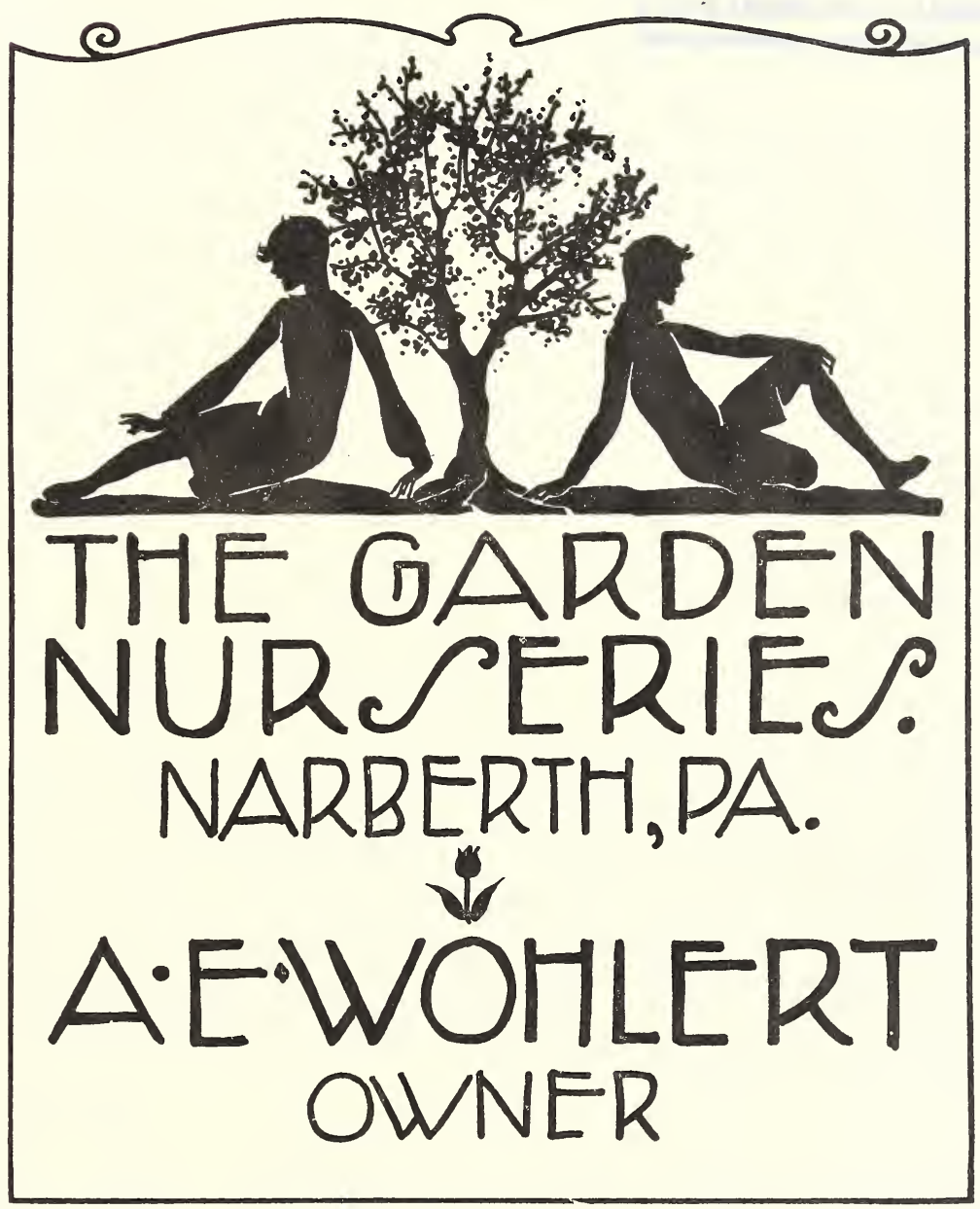


JAPAN ROSEFLOWERING CHERRIES is our leading specialty. We grow and sell probably more than ten times as many as any other nursery in America. Our trees are well spaced and frequently transplanted, the larger sizes mostly on own roots.

Our assortment is complete and covers all worthwhile varieties. There are dwarf sorts, columnar sorts, vase-shaped and spreading sorts, single or double, in 33 varieties. Our catalog on Flowering Trees describes thoroughly most of these varieties. If you do not already have a copy, ask for it.

\section{Each Price} in Lots of

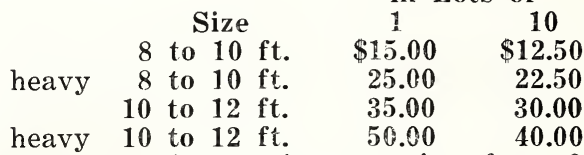

Japan Roseflowering Cherries may be had in all sizes ranging from 3 feet to 12 feet in height. See price list.

PRUNUS AMANOGAWA, Japanese Roseflowering Cherry, Double Pink, fragrant, columnar, fitted for small plantings and small gardens. Rare and new.

\begin{tabular}{|c|c|c|c|}
\hline \multirow[b]{2}{*}{ Size } & & Price in & 30 \\
\hline & 1 & 10 & 100 \\
\hline 8 to $9 \mathrm{ft}$. & $\$ 17.50$ & $\$ 12.50$ & $\$ 10.00$ \\
\hline 0 to $12 \mathrm{ft}$. & 35.00 & 30.00 & 25.00 \\
\hline 2 to $14 \mathrm{ft}$. & 50.00 & 40.00 & 30.00 \\
\hline
\end{tabular}

JAPAN WEEPING CHERRIES, pyramid form, grafted at the ground and branched from the ground up. The variety we use and grow is the only one that has stood the test of years: Variety Shidare-Higan Zakura. (A complete price list on all sizes is in our 1931 book.)

JAPAN WEEPING CHERRIES, pyramids, well spaced trees

\begin{tabular}{lrrrrr} 
& \multicolumn{3}{c}{ Size } & \multicolumn{1}{c}{1} & 10 \\
& 6 to $7 \mathrm{ft}$. & $\$ 10.00$ & $\$ 9.50$ \\
heavy & 7 to $8 \mathrm{ft}$. & 17.50 & $\mathbf{1 5 . 0 0}$ \\
heavy & 8 to $9 \mathrm{ft}$. & 25.00 & 20.00 \\
heavy & 9 to $10 \mathrm{ft}$. & 35.00 & 30.00 \\
heavy & 10 to $12 \mathrm{ft}$. & 50.00 & 45.00
\end{tabular}

Lighter trees sold for about $20 \%$ less.

An extra charge for packing Weeping Cherries on account of the peculiar spread of branches. Upright Japan Cherries, single or double, packed free of charge. No packing charge when shipped in bulk.

CHINESE MAGNOLIAS-Varieties available are Lenni, Alexandrina, Soulangeana, Alba Superba, Liliflorum, Purpurea, etc.

The sizes range up to 10 feet in fair abundance, a few of each variety up to 12 feet-all very broad and bushy. If 8 to 10 feet high, they are generally from 5 to 8 feet wide. One lot of Soulangeana and Alexandrina are 9 feet high down to 6 feet high, all or nearly all as wide as high. Most of the 6 to 7 feet high M. Soulangeana were transplanted Spring of 1931 . All sizes carry substantial balls.

MAGNOLIA SOULANGEANA

heavy stock, well budded, heavy balls when needed.

\begin{tabular}{|c|c|c|c|c|}
\hline \multirow{2}{*}{\multicolumn{3}{|c|}{ Size }} & \multicolumn{2}{|c|}{ in Lots of } \\
\hline & & & 1 & 10 \\
\hline 3 & to & ft. & $\$ 10.00$ & $\$ 8$. \\
\hline 4 & to 5 & ft. & 12.50 & 9.0 \\
\hline 5 & to 6 & ft. & 15.00 & 10.0 \\
\hline 6 & to 7 & ft. & 20.00 & 17.5 \\
\hline 7 & to 8 & ft. & 25.00 & 20.6 \\
\hline 8 & to 9 & ft. & 35.00 & 25.00 \\
\hline & to 10 & ft. & 50.00 & \\
\hline
\end{tabular}

Contrary to old superstition, Fall planting is at least as good as Spring planting, and by us preferred. 
MAGNOLIA ALEXANDRINA

Fine, bushy plants.

The 5 to 6 and 6 to $7 \mathrm{ft}$.

trees are as wide as high.

MAGNOLIA NIGRA

\section{MAGNOLIA GRANDIFLORA,}

Evergreen Magnolia

Popular in the South.

\begin{tabular}{|c|c|c|c|}
\hline & & $\begin{array}{c}\text { Ea } \\
\text { in }\end{array}$ & $\begin{array}{l}\text { rice } \\
\text { of }\end{array}$ \\
\hline & Size & 1 & 10 \\
\hline $3 \mathrm{t}$ & to $4 \mathrm{ft}$. & $\$ 12.00$ & \\
\hline $4 \mathrm{t}$ & to $5 \mathrm{ft}$. & 15.00 & \\
\hline & to $6 \mathrm{ft}$. & 20.00 & \\
\hline $6 \mathrm{t}$ & to $7 \mathrm{ft}$. & 25.00 & \\
\hline $18 \mathrm{t}$ & to $24 \mathrm{in}$. & 5.00 & $\$ 4.00$ \\
\hline $2 \mathrm{t}$ & to $3 \mathrm{ft}$. & 7.50 & 6.00 \\
\hline $3 \mathrm{t}$ & to $4 \mathrm{ft}$. & 10.00 & 7.50 \\
\hline $21 / 2 t$ & to $3 \mathrm{ft}$. & 8.00 & 7.50 \\
\hline & to $4 \mathrm{ft}$. & 10.00 & 9.00 \\
\hline
\end{tabular}

CHINESE FLOWERING CRAB in a wide assortment, grown as standards, as bushes branched from the ground (in 5 to 6 and 6 to 7 foot size there are frequently 6 to 8 branches from the ground up), high standards and low. Style of growth fit for hedges. Among the sorts adapted to that use, Malus Atrosanguinea, for instance, makes a perfect hedge that can be sheared if so desired.

Standard trees

Branched from ground up, 2 years older

Standard trees

Branched from ground up, heavy

Branched from ground up, heavy

Branched from ground up, heavy

Standard trees

A discount of $25 \%$ on quantities of one hundred or over of any one variety of the above sizes.

Heavy specimen

Heavy specimen

Heavy specimen

Heavy specimen

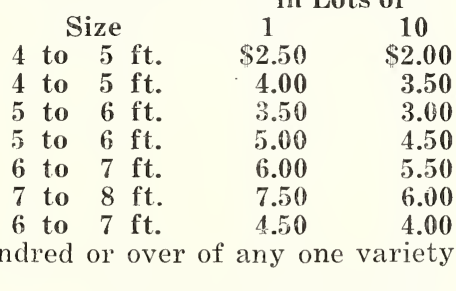

Each Price in Lots of

A few extra heavy trees can be had worth up to $\$ 150.00$ each. We grow over 25 varieties and can give very low prices on stock for screen planting 8 to 10 feet high, such as $\$ 300.00$ to $\$ 500.00$ per hundred. These sereen trees may be spaced four to six feet apart.

MALUS IOENSIS, Prairie Crab,

Standards, 3 to $4 \mathrm{ft}$. stem, 6 to $8 \mathrm{ft}$. spread, $1 / 2$ to $2 \mathrm{in}$. caliper.

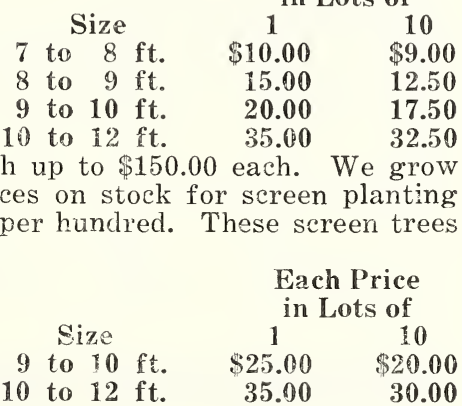

ACER PLATANOIDES, Norway Maple.

Choice well-grown trees.

$$
\begin{aligned}
& \text { Size } \\
& 11 / 2-13 / 4 \text { in. cal. } 10-12 \mathrm{ft} . \\
& 13 / 4-2 \text { in. cal. } 10-12 \mathrm{ft} . \\
& 2-21 / 4 \text { in. cal. } 12-14 \mathrm{ft} . \\
& 21 / 4-21 / 2 \text { in. cal. } 14-16 \mathrm{ft} \text {. } \\
& 21 / 2-3 \text { in. cal. } 16-20 \mathrm{ft} .
\end{aligned}
$$

100

$\$ 3.00$

3.50

4.50

5.50

6.50

\begin{tabular}{lrrrr} 
& & \multicolumn{2}{c}{ in Lots of } \\
BERBERIS THUNBERGI ATROPURPUREUM & \multicolumn{2}{c}{ Size } & \multicolumn{1}{c}{1} & 10 \\
Red-leaf Japan Barberry & 3 to $4 \mathrm{ft}$. & $\$ 6.50$ & $\$ 6.00$ \\
Specimen plants, extra & 4 to $5 \mathrm{ft}$. & 7.00 & 6.50 \\
heavy, 6 to 7 years old. & 5 to $6 \mathrm{ft}$. & 8.00 & 7.00
\end{tabular}


BUXUS SUFFRUTICOSA, Dwarf Box.
Each Price in Lots of

\begin{tabular}{|c|c|c|c|}
\hline Size & 1 & 10 & 100 \\
\hline 8 to $12 \mathrm{in}$. & $\$ 1.50$ & $\$ 1.00$ & $\$ 0.75$ \\
\hline 10 to 12 in. & 2.50 & 2.00 & 1.75 \\
\hline 2 to 14 in. & 3.50 & 3.25 & 3.00 \\
\hline to $16 \mathrm{in}$. & 4.50 & 4.00 & 3.5 \\
\hline 6 to 18 in & 5.00 & 4.50 & $4 .($ \\
\hline to 20 in. & 6.00 & 5.50 & 5.00 \\
\hline
\end{tabular}

Each Price in Lots of

\begin{tabular}{|c|c|c|c|}
\hline \multicolumn{2}{|c|}{ Size } & \multicolumn{2}{|c|}{$\begin{array}{ll}1 & 10\end{array}$} \\
\hline to & ft. & $\$ 25.00$ & $\$ 2$ \\
\hline to & ft. & 35. & 2 \\
\hline & & 50 & \\
\hline
\end{tabular}

9 to $10 \mathrm{ft}$. $\quad 50.00 \quad 40.00$
CEDRUS DEODARA, Deodar Cedar

Shapely and bushy,

6 to $8 \mathrm{ft}$. spread.

Transplanted last year.

Smaller plants can be had.

CHIONANTHUS VIRGINICA, White Fringe, Fringetree. Choice transplanted compact trees, very heavy.

4 to 5 feet at $\$ 7.50 ; 5$ to 6 feet at $\$ 10.00 ; 6$ to 7 feet at $\$ 15.00$.

CORNUS FLORIDA RUBRA, Pink Dogwood. Can be had in choice trees up to 9 feet high, transplanted two years ago. I will quote to you prices on a few sizes; we have them in all sizes. Dogwood Trees dug with a soil ball and burlapped any size from 3 to 6 feet $50 \mathrm{c}$ each additional, from 6 to 9 feet $\$ 1.00$ each additional.

CRATAGEUS, Hawthorne

Double Pink and Pauls

Scarlet varieties.

Very bushy specimens.

Ball and burlapped 50c each extra.

CRYPTOMERIA JAPONICA LOBBI

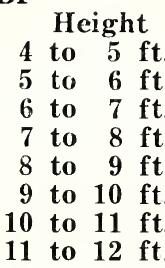

Each Price in Lots of

\begin{tabular}{lrrrr} 
& Size & \multicolumn{1}{c}{1} & 10 & 100 \\
3 to 4 ft. & $\$ 4.00$ & $\$ 3.00$ & $\$ 2.25$ \\
4 to 5 ft. & 5.00 & 4.00 & 3.50 \\
5 & to 6 ft. & $\mathbf{1 0 . 0 0}$ & 7.50 & 5.00 \\
6 to 7 ft. & 20.00 & 17.50 & $\ldots$ \\
7 to 8 ft. & 30.00 & 27.50 & $\ldots$ \\
8 to 9 ft. & 40.00 & 35.00 & $\ldots$ \\
5 to 6 ft. & 5.00 & 4.00 & $\ldots$ \\
6 to 7 ft. & 7.50 & 6.00 & $\ldots$ \\
7 to 8 ft. & 10.00 & 9.00 & $\ldots$ \\
8 to 9 ft. & 15.00 & 12.00 & $\ldots$
\end{tabular}

Each Price in Lots of

$\begin{array}{ccc}1 & 10 & 25 \\ \$ 10.00 & \$ 6.50 & \$ 5.00 \\ 15.00 & 10.00 & 7.50 \\ 17.00 & 12.50 & 10.00 \\ 25.00 & 20.00 & \ldots \\ 35.00 & 30.00 & \ldots \\ 40.00 & 35.00 & \ldots \\ \mathbf{5 0 . 0 0} & \mathbf{4 0 . 0 0} & \ldots \\ 75.00 & \mathbf{5 0 . 0 0} & \ldots\end{array}$

CYTISSUS LABURNUM, Goldenchain. Choice trees from 5 to 6 feet at $\$ 4.00$ up to 8 to 9 feet at $\$ 10.00 ; 9$ to $10 \mathrm{ft}$. at $\$ 15.00$.

FORSYTHIA PRIMULINUS

A rare new large flowering sort, extra good.

ILEX AQUIFOLIUM, English Holly

ILEX OPACA, American Holly

\begin{tabular}{rrrr} 
& & \multicolumn{2}{c}{ in Lots of } \\
5 to 6 ft. & $\$ 1$ & 10 \\
6 to 7 ft. & 5.00 & $\$ 2.00$ \\
7 to 8 ft. & 6.00 & 3.00 \\
2 to 3 ft. & 7.50 & 5.00 \\
3 to 4 ft. & 10.00 & 7.50 \\
4 to 5 ft. & 15.00 & 10.00 \\
5 to 6 ft. & 25.00 & 20.00 \\
5 to 6 ft. & 20.00 & 15.00 \\
6 to 8 ft. & 25.00 & 20.00 \\
10 to 12 ft. & 50.00 & 30.00
\end{tabular}




\section{ILEX (SERRATA) SEIBOLDI Japan Winterberry \\ Full of red berries now. \\ ILEX CRENATA, Japan Holly \\ Bushy, some with berries.}

JUNIPERS, including the varieties

Cannarti, Schotti, Burki,

Virginiana glauca

Specimen plants. Also

choice J. Chinensis columnaris.

JUNIPER PFITZERIANA

Specimens.

LIGUSTRUM, Green Privet

for screens, heavy.

LIGUSTRUM, Golden Privet

\begin{tabular}{|c|c|c|c|c|c|c|}
\hline & & & & Ea & rice in & $s$ of \\
\hline & & & ze & & 1 & 10 \\
\hline & & to & 3 & ft. & 3.00 & 2.50 \\
\hline & 3 & to & 4 & ft. & 4.00 & 3.50 \\
\hline & 4 & to & 5 & ft. & 6.00 & 5.00 \\
\hline & 5 & to & 6 & ft. & 7.50 & 6.00 \\
\hline & 20 & to 2 & 24 & in. & 7.50 & 6.00 \\
\hline & 24 & to 3 & 30 & in. & 10.00 & 7.50 \\
\hline & 30 & to 3 & 36 & in. & 15.00 & 12.50 \\
\hline & 3 & to & 4 & $\mathrm{ft}$. & 25.00 & 20.00 \\
\hline & 4 & to & 5 & fit. & 35.00 & 30.00 \\
\hline & 5 & to & 6 & ft. & 40.00 & 35.00 \\
\hline & 6 & to & 7 & ft. & 15.00 & 12.00 \\
\hline & 7 & to & 8 & ft. & 25.00 & 15.00 \\
\hline & 8 & to & 9 & ft. & 30.00 & 25.00 \\
\hline & 9 & to 1 & 10 & ft. & 40.00 & 35.00 \\
\hline & 10 & to 1 & 11 & ft. & 50.00 & 40.00 \\
\hline & 11 & to & 12 & ft. & 60.00 & 50.00 \\
\hline & 3 & to & 4 & ft. & 6.00 & 5.00 \\
\hline & 4 & to & 5 & $\mathrm{ft}$. & 8.00 & 6.00 \\
\hline & 5 & to & 6 & ft. & 10.00 & 8.00 \\
\hline & 6 & to & 7 & ft. & 12.50 & 10.00 \\
\hline & 7 & to & 8 & ft. & 15.00 & 12.00 \\
\hline & 8 & to & 9 & ft. & 15.00 & 12.00 \\
\hline & 9 & to 1 & 10 & ft. & 20.00 & 15.00 \\
\hline & 4 & to & 5 & ft. & 6.00 & 3.00 \\
\hline Sheared & 5 & to & 6 & ft. & 7.50 & 4.00 \\
\hline & 6 & to & 7 & ft. & 8.00 & 5.00 \\
\hline & 4 & to & 5 & ft. & 3.00 & 2.00 \\
\hline growth & 5 & to & 6 & ft. & 4.00 & 3.00 \\
\hline & 6 & to & 7 & ft. & 5.00 & 4.00 \\
\hline lea & $21 / 2$ & to & 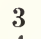 & ft. & 5.00 & 4.00 \\
\hline & & to & A & ft. & 8.00 & 7.50 \\
\hline & 4 & to & 5 & ft. & 3.50 & 3.00 \\
\hline & 5 & to & 6 & ft. & 4.50 & 3.50 \\
\hline
\end{tabular}

LIGUSTRUM LUCIDUM, Leather-leaf Evergreen Privet.

\section{LIGUSTRUM JAPONICUM}

\begin{tabular}{|c|c|c|c|c|}
\hline \multirow{5}{*}{$\begin{array}{l}\text { PERSICA, Flowering Peach. } \\
\text { Double Red and Double White. } \\
\text { Bushy, well branched, } \\
4 \text { to } 5 \mathrm{ft} \text {. spread, } 1 \text { to } 21 / 2 \mathrm{ft} \text {. ster }\end{array}$} & \multirow[b]{2}{*}{ Height } & \multicolumn{3}{|c|}{ Each Price in Lots of } \\
\hline & & 1 & 10 & 100 \\
\hline & 6 to $7 \mathrm{ft}$. & $\$ 6.00$ & $\$ 5.00$ & \\
\hline & 7 to $8 \mathrm{ft}$. & 7.50 & 6.00 & $\ldots$ \\
\hline & $\begin{array}{l}8 \text { to } 9 \mathrm{ft} \text {. } \\
\mathrm{ms} \text {. }\end{array}$ & 10.00 & 7.50 & $\ldots$ \\
\hline PICEA PUNGENS, Koster's Blue & 24 to 30 in. & 7.00 & 6.00 & \\
\hline $\begin{array}{l}\text { Spruce. } \\
\text { Transplanted } 1930 .\end{array}$ & 30 to 36 in. & 8.00 & 7.50 & \\
\hline PINUS MUGHUS, Mugho Pines & 18 to $24 \mathrm{in}$. & 3.50 & 2.50 & $\$ 2.00$ \\
\hline & 2 to $21 / 2 \mathrm{ft}$. & 5.00 & 3.50 & 3.00 \\
\hline & $21 / 2$ to $3 \mathrm{ft}$. & 6.00 & 5.50 & 5.00 \\
\hline & 3 to $31 / 2 \mathrm{ft}$. & 7.50 & 7.00 & . \\
\hline & $31 / 2$ to $4 \mathrm{ft}$. & 10.00 & 9.00 & \\
\hline PINUS NIGRA, Austrian Pine & $6 \mathrm{ft}$. & 8.00 & 7.50 & \\
\hline & $7 \mathrm{ft}$. & 12.00 & 10.00 & \\
\hline & 7 to $8 \mathrm{ft}$. & 20.00 & 16.00 & \\
\hline & 8 to $9 \mathrm{ft}$. & 25.00 & 20.00 & \\
\hline PINUS SYLVESTRIS, Scotch Pine & e 5 to $6 \mathrm{ft}$. & 7.50 & 6.00 & \\
\hline & $7 \mathrm{f}$ & 10.00 & 7.50 & \\
\hline
\end{tabular}


PINUS STROBUS, White Pine

Very heavy specimens,

6 to $8 \mathrm{ft}$. spread.

PINUS THUNBERGI, Japan Black Pine

\section{Height}

8 to $9 \mathrm{ft}$.

9 to $10 \mathrm{ft}$.

10 to $12 \mathrm{ft}$.

4 to $5 \mathrm{ft}$.

5 to $6 \mathrm{ft}$.

6 to $7 \mathrm{ft}$.
Each Price in Lots of

10

$20.00 \quad 17.50$

$25.00 \quad 20.00$

$40.00 \quad 30.00$

$6.00 \quad 5.00$

$8.00 \quad 7.50$

$10.00 \quad 8.00$

$10.00 \quad 6.00$

$15.00 \quad 7.50$

May Day Tree

Bushy, 5 to $6 \mathrm{ft}$. spread,

2 to $2 \frac{1}{2}$ in. caliper.

PYRACANTHUS COCCINEA and 4 to $5 \mathrm{ft}$. $6.00 \quad 5.00$

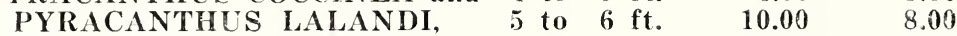

Field-grown, heavy, bushy specimens, wider than high, covered with berries.

\section{RETINOSPORA OBTUSA GRACILIS}

Shapely specimens, sheared,

2 to $3 \mathrm{ft}$. spread.

\begin{tabular}{llrr} 
& & \multicolumn{2}{c}{$\begin{array}{c}\text { Each Price } \\
\text { in Lots of }\end{array}$} \\
\multicolumn{2}{c}{ Height } & \multicolumn{1}{c}{1} & \multicolumn{1}{c}{10} \\
6 to $7 \mathrm{ft}$. & $\$ 25.00$ & $\$ 22.50$ \\
7 to $8 \mathrm{ft}$. & 30.00 & 27.50 \\
8 to $9 \mathrm{ft}$. & 35.00 & 32.50
\end{tabular}

RETINOSPORA (in the following sorts): Plumosa, Plumosa aurea, Pisifera, Pisifera aurea, Squarrosa, and Sulphurea, well grown, transplanted and sheared.

\begin{tabular}{|c|c|c|c|c|c|c|}
\hline & & & & Each & in Lot & \\
\hline & Height & & 1 & 10 & 25 & 50 \\
\hline $11 / 2$ & to 2 & ft. & $\$ 1.50$ & $\$ 0.90$ & $\$ 0.80$ & $\$ 0.75$ \\
\hline 2 & to $21 / 2$ & ft. & 1.75 & 1.00 & .90 & .80 \\
\hline $21 / 2$ & to 3 & ft. & 2.50 & 2.00 & 1.50 & 1.35 \\
\hline 3 & to $31 / 2$ & ft. & 3.50 & 3.00 & 2.50 & 2.25 \\
\hline $31 / 2$ & to 4 & ft. & 4.00 & 3.50 & 2.75 & 2.50 \\
\hline 4 & to 5 & it. & 5.00 & 4.50 & 3.75 & 3.50 \\
\hline 5 & to 6 & ft. & 7.50 & 6.50 & 6.00 & 5.75 \\
\hline 6 & to 7 & ft. & 12.00 & 7.50 & 7.00 & 6.25 \\
\hline 7 & to 8 & ft. & 15.00 & 10.09 & 8.00 & 7.50 \\
\hline 8 & to 9 & ft. & 16.50 & 12.50 & 11.00 & 10.00 \\
\hline 9 & to 10 & ft. & 20.00 & 15.00 & 14.00 & 12.50 \\
\hline
\end{tabular}

SORBUS AUCUPARIA, Mountain Ash. Choice, well-spaced trees full of fruit. 10 to $12 \mathrm{ft} ., \$ 40.00$ per $10 ; \$ 350.00$ per 100 12 to $14 \mathrm{ft} ., 60.00$ per $10 ; 400.00$ per 100 B. \& B. at $\$ 1.50$ each extra.

TAXUS CUSPIDATA, Japanese Yew Slow growing, perfectly hardy.
TAXUS CUSPIDATA CAPITATA, Upright Japanese Yew. Of upright growth, dense green foliage; slow growing.
Each Price in Lots of.

\begin{tabular}{|c|c|c|c|c|}
\hline \multicolumn{3}{|c|}{ Height } & 1 & 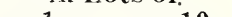 \\
\hline 12 & to 15 & in. & $\$ 2.25$ & $\$ 2.00$ \\
\hline 15 & to 18 & in. & 3.75 & 3.50 \\
\hline 18 & to 22 & in. & 5.50 & 5.00 \\
\hline 22 & to 24 & in. & 7.00 & 6.00 \\
\hline 2 & $21 / 2$ & ft. & 10.00 & 7.50 \\
\hline $21 / 2$ & to & ft. & 17.50 & 15.00 \\
\hline 3 & $31 / 2$ & ft. & 20.00 & 17.50 \\
\hline $31 / 2$ & to & ft. & 25.00 & 20.00 \\
\hline 4 & to & ft. & 30.00 & 25.00 \\
\hline 5 & to & ft. & 40.00 & 35.00 \\
\hline 3 & $31 / 2$ & ft. & 15.00 & 14.00 \\
\hline $31 / 2$ & to & ft. & 25.00 & 20.00 \\
\hline 4 & to 5 & ft. & 35.00 & 32.50 \\
\hline 5 & to & ft. & 40.00 & \\
\hline & to & ft. & 50.00 & \\
\hline
\end{tabular}




\begin{tabular}{|c|c|c|c|c|}
\hline & & & $\begin{array}{c}\text { Eac } \\
\text { in }\end{array}$ & $\begin{array}{l}\text { ice } \\
\text { of }\end{array}$ \\
\hline & Size & & 1 & 10 \\
\hline 15 & to 18 & in. & 5.00 & 4.50 \\
\hline 18 & to 24 & in. & 10.00 & 9.00 \\
\hline 2 & to $21 / 2$ & ft. & 12.50 & 11.00 \\
\hline $21 / 2$ & to 3 & ft. & 15.00 & 12.50 \\
\hline 0.72 & to 4 & $\mathrm{ft}$. & 25.00 & 20.00 \\
\hline 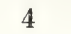 & to 5 & ft. & 35.00 & 30.00 \\
\hline
\end{tabular}

THUJA OCCIDENTALIS, American Arborvitae. Grown well spaced to a single leader. Double leaders and more can be had to a limited extent up to 6 to 7 feet.

\begin{tabular}{|c|c|c|c|c|c|c|}
\hline \multirow{2}{*}{\multicolumn{2}{|c|}{ Height }} & & & & & \\
\hline & & 1 & 10 & 25 & 50 & 100 \\
\hline 3 & to $4 \mathrm{ft}$. & $\$ 1.50$ & $\$ 1.25$ & $\$ 1.10$ & $\$ 1.00$ & $\$ 0.90$ \\
\hline 4 & to $5 \mathrm{ft}$. & 2.50 & 2.00 & 1.80 & 1.50 & 1.30 \\
\hline 5 & to $6 \mathrm{ft}$. & 4.00 & 3.50 & 3.25 & 3.00 & 2.75 \\
\hline 6 & to $7 \mathrm{ft}$. & 6.50 & 6.00 & 5.50 & 4.50 & 3.75 \\
\hline 7 & to $8 \mathrm{ft}$. & 7.00 & 6.50 & 6.25 & 6.00 & 5.90 \\
\hline 8 & to $9 \mathrm{ft}$. & 10.00 & 9.50 & 9.00 & 8.50 & 8.00 \\
\hline 9 & to $10 \mathrm{ft}$. & 12.50 & 10.00 & 9.50 & 9.00 & 8.75 \\
\hline 10 & to $12 \mathrm{ft}$. & 15.00 & 12.50 & 10.00 & & \\
\hline 12 & to $14 \mathrm{ft}$. & 20.00 & 15.00 & 14.00 & $\ldots$ & \\
\hline
\end{tabular}

THUJA OCCIDENTALIS PYRAMIDALIS, Pyramidal Arborvitae. Pyramidal Arborvitae grown for fancy retail trade, almost all to one central lead. A few can be had of many branches; in sizes over 7 feet more many-branched trees can be had. We prefer one lead.

\begin{tabular}{rrrrrrr}
\multicolumn{3}{c}{ Height } & \multicolumn{5}{c}{ Each Price in Lots of } \\
2 to $3 \mathrm{ft}$. & $\$ 2.50$ & $\$ 2.00$ & $\$ 1.25$ & $\$ 1.00$ & \multicolumn{1}{c}{$\$ 0.75$} \\
3 to 4 ft. & 3.50 & 2.75 & 1.75 & 1.50 & 1.25 \\
4 to 5 ft. & 5.00 & 4.00 & 2.75 & 2.50 & 2.00 \\
5 to 6 ft. & 5.50 & 4.50 & 3.75 & 3.25 & 2.75 \\
6 to 7 ft. & 6.00 & 5.50 & 5.00 & 4.50 & 4.00 \\
7 to 8 ft. & 8.50 & 7.00 & 6.50 & 6.00 & 5.50 \\
8 to 9 ft. & 10.00 & 8.50 & 8.00 & 7.50 & 7.25 \\
9 to 10 ft. & 12.00 & 10.00 & 9.50 & 8.50 & 8.00 \\
10 to 12 ft. & 15.00 & 12.50 & 11.00 & 9.50 & 9.00 \\
12 to 14 ft. & 20.00 & 15.00 & 12.50 & 10.00 & 10.00
\end{tabular}

TSUGA CANADENSIS, Canadian

Hemlocks. Extra choice shapely plants.

\begin{tabular}{|c|c|c|c|c|}
\hline & & & Price il & ts of \\
\hline & Height & 1 & 10 & 100 \\
\hline & $5 \mathrm{ft}$. & $\$ 7.50$ & $\$ 6.25$ & $\$ 6.00$ \\
\hline & $6 \mathrm{ft}$. & 8.50 & 7.50 & 7.00 \\
\hline & $7 \mathrm{ft}$. & 9.00 & 8.75 & 8.00 \\
\hline & $8 \mathrm{ft}$. & 15.00 & 12.00 & 10.00 \\
\hline 9 to & $10 \mathrm{ft}$. & 20.00 & 15.00 & 12.50 \\
\hline 10 to & $12 \mathrm{ft}$. & 25.00 & 18.00 & 15.00 \\
\hline 12 to & $14 \mathrm{ft}$. & 30.00 & 21.00 & 20.00 \\
\hline & & & $\begin{array}{l}\text { Eac } \\
\text { in }\end{array}$ & $\begin{array}{l}\text { ice } \\
\text { of }\end{array}$ \\
\hline & & Height & 1 & 10 \\
\hline & & ft. & $\$ 7.50$ & $\$ 5.00$ \\
\hline & & $31 / 2 \mathrm{ft}$. & 10.00 & 7.50 \\
\hline & & $4 \mathrm{ft}$. & 12.00 & 10.00 \\
\hline & & 5 ft. & 15.00 & 12.50 \\
\hline & & $2 \mathrm{ft}$. & 4.00 & 3.00 \\
\hline & & $2 \mathrm{l} / 2 \mathrm{ft}$. & 5.00 & 4.00 \\
\hline & & $3 \mathrm{ft}$. & 6.00 & 5.00 \\
\hline & & 4 ft. & 7.50 & 6.50 \\
\hline & & $41 / 2 \mathrm{ft}$. & 10.00 & 9.00 \\
\hline & 5 to & $6 \mathrm{ft}$. & 12.00 & 10.00 \\
\hline & 6 to & 7 ft. & 15.00 & 12.00 \\
\hline & 7 to & ft. & 20.00 & 15.00 \\
\hline
\end{tabular}

VIBURNUM CARLESI, heavy plants, $31 / 2$ to 5 ft. spread.

Old plants imported from Korea.

Home-grown, transplanted 1930 , on own roots.

WISTARIA, Chinese Purple, bush form, heavy, 10 years old.

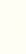



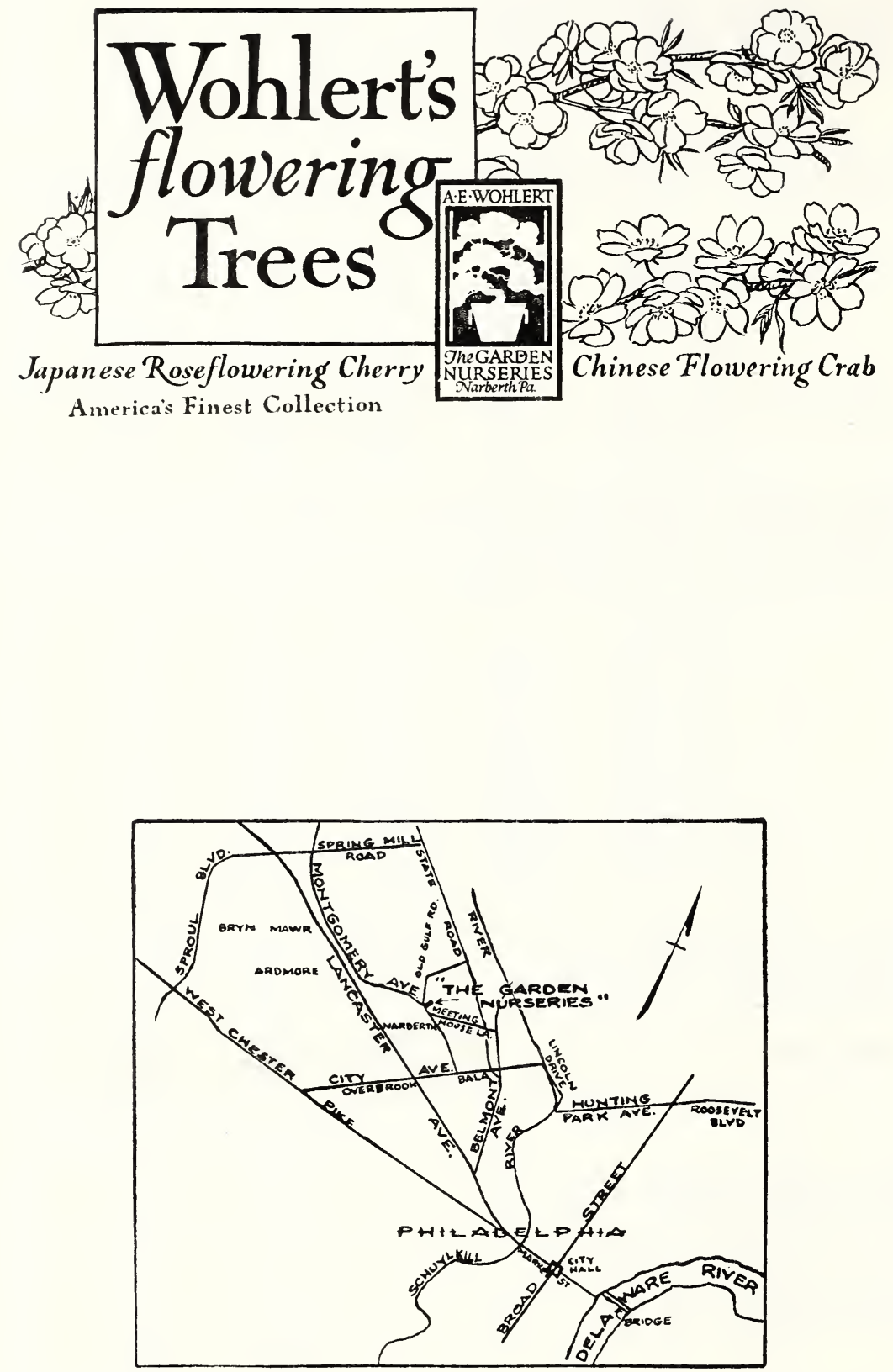